\title{
THE PLEISTOCENE NON-MARINE MOLLUSCA OF ILFORD.
}

\author{
By A. S. Kennard and B. B. Woodward, F.G.S., F.R.M.S.
}

(Read June 2nd, 1899 .)

IN 1890 an account of the non-marine nollusca from this 1 locality was read before the Association by one of us, and was published in the Proceedings.* Since then Dr. Frank Corner, M.R.C.S., F.G.S., has collected extensively at Ilford, and the results of his labours were given by us in $1897 . \dagger$ During the last four years Mr. M. A. C. Hinton has also worked at these beds, and he very kindly placed his collection at our service. We now possess a fair knowledge of the mollusca from the Pleistocene brick-earths of Ilford. In the first place it must be remarked that the older collections were all made from the Uphall pit, whilst the specimens in the cabinets of Messrs. Corner and Hinton were obtained from the pit variously known as Sam's Green, Page's or the Cauliflower pit. Since the Uphall examples are from a slightly lower level, there is perhaps a difference in age, and it is advisable to list them separately on this account. With regard to the occurrence of the Uphall specimens Dr. Cotton remarked, "The two genera of shells of which hundreds may often be obtained at one visit are Helix and Cyrena, but Unio and Planorbis are not uncommon, and Ancylus, Succinea, Valvata, Limnaus, Cyclas, and Paludina have been discovered. They are chiefly seen in the layers of sand upon which the brick-earth reposes, and beneath the bones that are sometimes intermixed with them, and have been found even within their cavities. They appear to be partial in their distribution, and are not met with in the former cutting " [i.e., on the North side of London Road, Curtis' brickfield]. \$ The examples from Sam's Green pit are scarce and occur chiefly at one level, but single examples may be found scattered throughout the mass of brick-earth. In spite of the former abundance of shells in the Uphall pit hardly any trouble was taken to collect examples; but it is quite possible that many specimens may still exist in old collections. There are only two series known to the Authors, one in the Natural History Museum, and the other in the Museum of Practical Geology. Twenty-two species are represented, viz. :

* B. B. Woodward, "On the Pleistocene (Non-Marine) Mollusca of the London District," Proc. Geol. Assoc., vol. xi, pp. 335-338.

$\dagger$ A.'S. Kennard and B. B. Woodward, "The Post-Pliocene Non-Marine Mollusca of Essex," Essex Naturalist, vol. x, pp. 87. rog.

$\ddagger$ R. P. Cotton, "On the Pliocene Deposits of the Valley of the Thames at Ilford," Ann. and Mag. Nat. Hist. xx (1847), p. 165.

February, I 900.] 
THE PLEISTOCENE NON-MARINE MOLLUSCA OF ILFORD. 283

Vitrea nitida (Müll.).

Eulota fruticum (Müll.).

Vallonia pulchella (Müll.).

Hygromia hispida (Linn.).

Helicella caperata (Mont.).

Helix nemoralis, Linn.

Cochlicopa lubrica (Müll.).

Succinea putris (Linn.).

Limnaa pereger (Müll.).

, palustris (Müll.).

", truncatula (Müll.).
Planorbis albus, Müll.

" marginatus, Drap.

$" \quad$ lineatus (Walk.).

Bythinia tentaculata (Linn.). leachii (Shepp.).

Valvata piscinalis (Müll.).

Unio pictorum (Linn.).

, tumidus, Retz.

Corbicula fluminalis (Müll.).

Pisidium amnicum (Müll.).

" fontinale, Drap.

The following nine species have been recorded, but no examples of them are known :

Vitrea fulva (Müll.).

Pyramidula ruderata (Stud.).

Pupa muscorum (Linn.).

Vertigo antizertigo (Drap.).

\section{Planorbis corneus (Linn.).}

Succinea oblonga, Drap.

Carychium minimum (Müll.).

Ancylus fluviatilis, Müll.

Limnea auricularia (Linn.).

There is no inherent improbability in any of these records, but it would be more satisfactory if examples were known of Pyramidula ruderata (Stud.). The record is on the authority of Dr. J. Gwyn Jeffreys, who, in 1869, during the discussion following a paper by Professor W. Boyd Dawkins "On the Distribution of the British Postglacial Mammals,"* mentioned that this species and Eulota fruticum occurred at Ilford. Examples of the latter are, of course, known, but Mr. W. H. Dall informs us that there are no examples of $P$. ruderata in Dr. Jeffreys' collection, which is now at Washington. It is extinct in this country, and is only known fossil from three localities, Barnwell, Copford, and Clacton, although, of course, it is still an abundant form on the Continent, ranging as far north as Sweden.

Dr. Corner's collection from San's Green pit contained twenty-four species, whilst twenty-seven were represented in Mr. Hinton's, the combined list showing a total of thirtyfour, viz. :

Vitrea nitida (Müll.). nitidula (Drap.).

Vallonia pulchella (Müll.).

Hygromia hispida (Linn.).

Helicigona arbustorum (Linn.).

Helix nemoralis, Linn.

Helicella virgata (Da Costa). caperata (Mont.).

Pupa cylindracea (Da Costa). muscorum (Linn.).

Vertigo antivertigo (Drap.).

Succinea putris (Linn.).

" elegans, Risso.

Limnea pereger (Müll.).

" pahustris (Müll.).

" truncatula (Müll.).

$"$ stagnalis (Linn.).

", glabra (Müll.).

Planorbis glaber, Jeff.

” carinatus, Müll.

\footnotetext{
* Quart.Joum. Geol. Soc., vol. xxv, p. 192.
} 
Planorbis marginatus, Drap.

$" \quad$ vortex (Linn.).

" spirorbis (Linn.).

" contortus (Linn.).

"lineatus (Walk.).

Bythinia tentaculata (Linn.).

Valvata piscinalis (Müll.).
Valvata cristata, Müll.

Corbicula fluminalis (Müll.). Anodonta cygnaa (Linn.). Spharium corneum (Linn.). Pisidium amnicum, Müll.

$" \quad$ astartoides, Sandb. " pusillum (Gmel.).

Of these no less than sixteen species are unknown from Uphall, whilst there are seven species from that locality as yet unrecorded from Sam's Green pit. Two species, Vertigo antivertigo and Pupa muscorum, recorded from Uphall, but of which no specimens can be traced, are now listed from Sam's Green pit.

\section{Notes on the Species from Sam's Green Pit.}

Helicella virgata is represented by a single example, and its occurrence is of great interest, since it is unknown in any other deposit, either Pleistocene or Holocene, of the Thames Valley. It was fairly common in the Pleistocene of Barnwell, and is not rare in a hill-wash, of Neolithic age, at St. Catherine's Down, Isle of Wight. Elsewhere it is unknown in any pre-Roman deposit, though, at the present day, it is one of the most abundant shells, and is gradually extending its range.

Pupa cylindracea has an even more curious geological history. It is known from the Norwich Crag at Bramerton, and has been recorded (but no specimens are known) from Clacton. It was common at Copford, but the age of that deposit is uncertain. It also occurs in similar beds at Chignal St. James', Felstead, Roxwell, and Shalford.

Of particular interest was a Limnea, which differed so much from all recent British forms that we invoked the aid of Dr. O. Boettger, of Frankfort, who informed us that it was quite new to him, but was near $L$. palustris, var. diluviana, and this example, with other Ilford shells, was presented to the Natural History Museum by Dr. Corner. It is to be hoped that more examples of this form may yet be found.

Vitrea nitidula has hitherto been unrecorded from Ilford. This species is known from the Pleistocene of Barnwell, of northeast London, and from Copford. It has been recorded from Grays by Mr. S. V. Wood, but no examples can be traced.

All the examples of Corbicula fluminalis from Sam's Green pit are immature. An example of the dwarfed form of Limnaa palustris, which occurs in the Pleistocene of Harwich and Crayford, is in Mr. Hinton's collection.

Planorbis vortex is only represented by two examples; whilst $P$. spirorbis is the most abundant of the genus. Valvata piscinalis, so abundant at Grays, Crayiord, and other Pleistocene localities, 
is only represented by four examples of the normal form. The variety known as $V$. antiqua, Sby., has not been met with. The characteristic Pleistocene forms, Planorbis glaber and Pisidium astartoides, are also of great interest.

The occurrence of a single example of Limnaa glabra is of the greatest importance. This species is at the present day a widely-distributed form in these islands, but it has not hitherto been recorded fossil. It was unlikely that so widespread a form should be a recent introduction, and the Ilford example enables us to fill up a gap in the geological record.

It will thus be seen that recent work in this well-studied locality has greatly added to our knowledge, and we trust that the good work may be extended to other Pleistocene deposits, and so enable us to present an accurate list of their contained fossils.

[Since this paper was read Mr. J. P. Johnson has called our attention to a large series of mollusca in his collection, obtained at Uphall. There are thirty-one species represented, of which no less than fourteen are new records, viz. :

\begin{tabular}{|c|c|}
\hline & \\
\hline $\begin{array}{l}\text { laxagr } \\
\text { rystallit }\end{array}$ & $\begin{array}{l}\text { n.). } \\
\text { (a) }\end{array}$ \\
\hline Arion & laminata (Mont.) \\
\hline Punctum pygmceum (Drap.) & Planorbis glaber, Jeff. \\
\hline Pyramidula rotundata (Müll.) & Paludestrina marginata (Mich.) \\
\hline Helicella itala (Linn.) & ventrosa (Mont.) \\
\hline Helix hortensis, Müll. & ata, Müll. \\
\hline
\end{tabular}

There are five other species of which, though previously recorded from Uphall, no other examples are known to be extant, viz. :

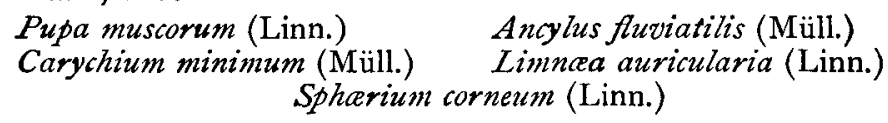

Arion ater is indeed an interesting find, because it is a new record for the English Pleistocene, though it is known from deposits in France of the same age, and we have recently found it in several English Holocene beds. Agriolimax agrestis is now known from Ilford, Grays, and Crayford.

Punctum pygmaum is rare in any deposit, though it has been found at Copford, Barnwell, and West Wittering, in beds probably of Pleistocene age.

The occurrence of a single example of Helix hortensis furnishes additional proof of the presence of this form in this country in Pleistocene times. Paludestrina marginata is one of those species now extinct in this country which are of great interest. It occurs at Grays, but so far has been undetected at Crayford. The examples of Spherium corneum are of the form so common at Crayford and known on the Continent as Spharium mananum, Kobelt. 
The presence of several examples of Paludestrina ventrosa is noteworthy as tending to support the theory of more estuarine conditions than now exist. The numbers of species given above are of course materially altered by these new records.

We are greatly indebted to Mr. Johnson for his kindness in placing his collection at our service.]

\section{ORDINARY MEETING.}

Friday, 3RD November, I899.

J. J. H. Teall, M.A., F.R.S., President, in the Chair.

The following were elected Members of the Association: F. Coutts Antrobus, H. Arnold-Bemrose, M.A., F.G.S., W. B. Bannerman, F.L.S., F.G.S., James R. Brown, J. Herbert Hodd, F. Praed, H. Alfred Roechling.

The meeting then resolved into a Conversazione, and the following is a list of the exhibitors and their exhibits :

The Director-General of the Geological Survey: Sheets I 55, 248 (Drift and Solid), 282, 300, 315, 349, and 350 of the Geological Map of England and Wales, and Sheets 19, 85 , and 115 of the Geological Map of Scotland.

J. J. H. Teall, M.A., F.R.S. : Corundum from Scotland.

W. P. D. Stebing, F.G.S. : The Association's Album of Geological Photographs; Crocidolite from S. Africa, Tertiary Ironstone from Frythe Park, near Epsom, and silicified Wood from Arizona.

A. E. Salter, B.Sc., F.G.S. : Erratic igneous Rocks, consisting of Dolerites (Diabases), Rhyolites, etc., and microscopic slides of the same, from the Lea Valley, Cromer, Derbyshire, and various other localities.

Dr. G. Aввотт : Various types of Concretions in Limestone, Iron, and Silica.

A. K. Coomara-Swamy, F.G.S. : Corundum and other minerals from Ceylon, Sections of Rocks from Ceylon and Brittany, and Cambrian Fossils from Skye.

W. H. Chadwick and Percy Emary, F.G.S. : A series of Graptolites from the Wenlock Shale and Llandeilo Beds of Builth and Llandrindod, and from the Llandeilo Beds of Abereiddy Bay, near St. David's.

Prof. T. G. Bonney, D.Sc., LL.D. : "Dreikanter" (windworn stones) from Egypt and New Zealand; and Schistose Jurassic rocks with minerals mistaken for garnets and staurolites, etc., from the Alps.

F. A. Bather, M.A., F.G.S. : A quartzite Pebble from a Drift at Bowdon, Cheshire, with three facets on one surface (the property of R. D. Darbishire, Esq.); also similarly shaped pebbles from near Reval in Esthland, from Hokitika, New Zealand, FEBRUARY, Igoo.] 